\title{
Sourcing stone for the conservation and repair of the buildings and monuments of Britain
}

Graham Lott

\section{Abstract}

Stone for the construction of buildings and monuments has been locally quarried from most parts of Britain's lithologically diverse geological succession for the last 3500 yrs. Each part of the geological column, from the Precambrian to Quaternary, has yielded stone for building providing a colourful palette of stones for Britain's stone architecture and monuments. For those involved in conserving these structures this diversity of stone types has itself become an increasing problem as many of the original quarries have long since stopped working and the stones disappeared from the marketplace. This lack of an adequate range of indigenous stones suitable for conservation repair and for sympathetic new build projects is an ongoing concern for heritage organisations, property owners and developers in Britain. There are a number of ways in which this problem is being addressed. It is clearly important to demonstrate the scale of the problem by collating sufficient information to identify those stones (and therefore those stone structures) most under threat. While some vernacular stones were used widely others often only appear in a small number of buildings. A national database of all indigenous stone sources used and an assessment of their extent of use is therefore essential. Subsequent analysis of the data gathered will then allow the identification of those stones which are of critical concern and which might then generate sufficient interest and economic potential for quarry operators to consider re-opening sites for new stone production. This review is an attempt to give an overview of the former extent of the building stone resources of Britain to illustrate the extent of the current problems of stone supply. 


\section{Introduction}

The problem of sourcing suitable building stones for any building project is not a new issue. In early stone buildings or structures the original choice of stone was inevitably restricted by problems of transportation, which could reduce choice and increase costs significantly. Building stones are heavy and not easily moved far from their quarry source. Many early stone sources were, therefore, often located close to the construction site or along river courses or near the coast, enabling the stone to be easily and presumably more cheaply transported to the building site. Kentish Ragstone, for example, from the Lower Cretaceous of Kent generally only suitable as rubblestone, was used extensively in London from Roman times primarily because the numerous Ragstone quarries had easy access to the city using the River Medway and its tributaries, allowing the stone to be easily and cost-effectively sourced. At the same time the lack of a local stone, more suited for ashlar block and fine carving, in south east England in general, saw the development of a significant import trade bringing Middle Jurassic limestone from the coastal quarries of Caen in Normandy. Although good quality freestones were being worked at this time elsewhere in Britain it was clearly easier and cheaper, though occasionally more risky, to import this finely bioclastic limestone from across the English Channel rather than consider other indigenous British limestones (Salzman 1967). Although indigenous British stone usage did expand gradually from the $11 \mathrm{C}$ to $17 \mathrm{C}$, it was not able to reach wider national markets until the late $18 \mathrm{C}$ and $19 \mathrm{C}$, when suitable canal, rail and finally road networks were established, transforming traditional patterns of building stone supply and usage.

Determining original sources of stone supply for any standing building is a fundamental part of sourcing stone for conservation repair, but can also be important in discouraging new-build projects out of context with their local setting. Ideally information regarding stone sources should be acquired from original documentary evidence but, with the exception of high status buildings, experience tells us that the older the building the less likely it is that such information has survived, at least in documentary form. The principal source of information then becomes the stones themselves. Modern geological / geotechnical assessments of Britain's building stones date back to the early 19 C (e.g. Barry et al. 1839; Hull 1872) but 'modern' microscope petrographical techniques have only been developed since the early $20 \mathrm{C}$. As yet no comprehensive text on the general petrographic characteristics of British buildings stones has appeared since the publication by Warnes (1926). Increasingly petrographic analysis of stones has become an essential part of any stone sourcing exercise. It can reveal not only the geological source of the stone but can also provide information on its weathering characteristics and general durability. Occasionally of course it will also raises the thorny issue of whether it is always appropriate to advise the replacement of one already badly failed stone, with the same stone in order to give apparent, but probably temporary authenticity to the repair.

When dealing with stone identification and replacement in some of Britain's historic buildings it is important to consider the history of each building. Many have already undergone several phases of repairs, alterations and additions not simply because the original stones were no longer available but because they were judged to be of poor quality having 'only' survived 4 or 5 hundred years! Much of this restoration work was often undertaken using a variety of quite different replacement stones. In a number of iconic London buildings, for example, including Westminster Abbey (11-20 C), Buckingham Palace (18-19 C) and the Palace of Westminster (19-20 C) the original stone fabric can 
now only be seen in exposed internal stonework as the external facades have often been partially or completely refaced. In parts of Westminster Abbey the main façade has most recently been refaced with white Portland Stone (Upper Jurassic ooidal limestone), replacing an earlier badly decayed pale yellow Bath Stone (Middle Jurassic ooidal and bioclastic limestone), which in its turn replaced the original medieval stone fabric comprising a mix of Lower Cretaceous calcareous sandstones (Kentish Ragstone, Reigate Stone) and Caen limestone (Brown et al 1963). By contrast, in the 'new' Palace of Westminster, even the careful selection of the original Anston Stone (Permian dolomitic limestone) by a team of experts, proved to have been a serious error and much of the original fabric has now in large part been replaced piecemeal, with Clipsham and Ketton stones -Middle Jurassic, bioclastic and ooidal Lincolnshire limestones (Barry et al 1835; Schaffer, 1955; Lott \& Richardson 1997). In Oxford the problems caused by the use of the local Headington Stone (Upper Jurassic, Corallian Group limestone) has seen many of its historic $17 \mathrm{C}$ college buildings completely refaced with Middle Jurassic ooidal and bioclastic limestones from the Lincolnshire or Bath quarries in the late $19 \mathrm{C}$ (Arkell 1947; Smith \& Viles 2006).

These rather dramatic stone 'conservation' projects are examples of some of the more high profile attempts to deal with severe stone decay, which in fact were probably compounded by general neglect and a lack of available matching replacement stone, rather than a direct result of the quality of the original stones, which in some cases had actually survived for several hundred years. A similar story of stone replacement or mismatched repair on a smaller, much less well publicised scale has been mirrored in vernacular stone buildings and monuments of all types across Britain. Poor the maintenance of buildings in the more recent past and the 'new' problems caused by the legacy of industrial pollution from the 19 and early $20 \mathrm{C}$ are principally to blame, but have not been helped by the lack of availability of many of our indigenous building stones for use in repairs. Currently there are c. 329 active building stone quarries in Britain compared with more than 2000 quarries in the mid- $19 \mathrm{C}$, and evidence in from its surviving vernacular buildings of many more sources prior to that date (e.g. Lott 2008).

\section{Building stone use in Britain}

While the durability of stone as a construction material was clearly appreciated from earliest times (e.g. Sarsen sandstone (Tertiary), used in Stonehenge 3500 yrs B.P.) the problems of transportation still precluded the wider use of most building stones far from their local quarries (e.g. Senior 1989). However, as the quality and prestige associated with the use of stone became more apparent its use in buildings far from their quarry sources gradually became more common. Powerful organisations and individuals, notably the Crown, the State and the Church soon recognised the kudos associated with having a prestigious stone building as their main residence or headquarters. Only they had sufficient wealth to consider transporting selected stones far from their local area and they frequently did so. Well documented examples include the Lincolnshire Limestone quarries in the East Midlands which in medieval times had well established transportation routes using the local waterways for the construction of several Fenland abbeys and churches (Purcell 1965). Some stones took rather longer than others to reach the seats of power in London including the now ubiquitous white ooidal Portland Stone which was first used there by Ingo Jones in 1622 in his new Banquetting Hall in Whitehall, along with stones from Oxfordshire, Northamptonshire and Yorkshire (Huddleston Stone) (Cox \& Norman, 1930). London gradually became a key market for many other regional 
stones including, for example Cumbrian (Lakeland) roofing slates for the houses of the gentry in the 18 C (Tyson 1984).

The dramatic and often competitive expansion of many of Britain's industrial cities and towns in the $19 \mathrm{C}$, increased the demand for stone for their more prestigious civic and industrial building projects, as well as for the massive new housing developments needed for their growing industrial workforces. Building stone production from the Pennines area expanded almost exponetially, introducing many more sandstone varieties onto the national market. Some, including the Elland Flagstones (Carboniferous), well known locally for their durable, traditional hand-riven paving sandstones, were increasingly in demand in London and other UK cities. Others, like Bath Stone limestones (Middle Jurassic) having dominated the local building stone market in the City of Bath and surrounding area since the late $17 \mathrm{C}$, also began to reach into London and other UK cities and towns. The major improvements in railway transportation introduced roofing slates from the remoter quarrying areas of North Wales, England (Cumbria and Devon) and Scotland (Argyllshire, Highlands, Aberdeenshire and Banffshire), to their wider national markets. The quality of Welsh slate has enabled the industry to continue to supply wider international markets in America, South Africa and Australia.

In the latter part of the $20 \mathrm{C}$, following two world conflicts, a decline in the stone quarrying industry in general resulted in sharp reduction in Britain's indigenous stone supplies. Many older local quarries closed during this period and did not reopen. This precipitated something of a change in emphasis in the approach to the conservation of Britain's stone buildings and monuments. Stone repairs made during this period were now not necessarily based on careful matching to the original stone used, but were constrained by the limited choice of stones still available in the market place. It is still common, for example, in many church buildings throughout Britain to see a much more ad hoc use of different stones and other materials in late 19 \& $20 \mathrm{C}$ fabric repairs. The materials used often bearing little or no relationship to the stone used in the original fabric, but appear at times to largely reflect whatever stones happened to be left in the local mason's yard!

\section{The geology of Britain's building stones}

The lithological diversity of Britain's geological outcrops has meant that thousands of former building stone quarries can be identified in the landscape. Most quarries probably began as sources of local rubblestone used for the construction of field walls, shelters or small vernacular buildings with probably little or no consideration given to their long term durability. Over time as building techniques improved and changed, however, the requirement for better quality stones, suitable for ashlar block and carved stonework soon increased. Thousands more new quarries became established, only a small proportion of which have survived and developed to form the core of Britain's modern building stone industry (Plate 1; Lott 2001).

\section{Britain's building limestone resources}

The principal limestone sources in Britain lie within its Silurian, Devonian, Carboniferous, Permian, Jurassic and Cretaceous successions. With experience limestones from each of these geological systems are generally sufficiently different in geological character to enable their provenance to be 
determined when out of context in a building or even, where they have travelled far from their original quarry sources.

Britain's building limestones can be subdivided into a number of broad lithological / petrographic types. The majority are composed of calcium carbonate and include - finely crystalline (muddy or micritic) and coarsely crystalline (sparry) limestones, bioclastic (whole and broken fossil fragments) and ooidal (ooid-dominated) limestones. Most limestones contain a variable mix of these framework grains in a fine micritic matrix or sparry calcareous cement. The micritic building limestones principally include those of the late Triassic (White Lias), the Lower Jurassic ('Blue' Lias) Upper Cretaceous (Chalk Group) and the early Tertiary (Palaeogene) successions. The coarse grained 'granular' ooidal and bioclastic building limestones are principally found in the Devonian, Carboniferous, Jurassic, Cretaceous and Tertiary successions. Some fossiliferous limestone lithologies, formed as reefs or bioherms, were not used as building stones, but were often quarried to produce polished decorative stones e.g. Frosterley and Derby Fossil 'marbles'. The particularly distinctive highly porous, freshwater limestones deposits during the Quaternary and known as tufa, were locally exploited for building stone in many parts of Britain. There are a number of hybrid stones comprising a variable mix of carbonate (bioclasts, ooids etc) and terriginous grains (quartz, feldspar etc), usually with a carbonate cement or micritic matrix, most notably perhaps including the Kentish Ragstone (Lower Cretaceous).

Also included in the building limestones of Britain are the dolomitic varieties (dolostones), which are composed predominantly of magnesium carbonate (dolomite) rather than calcium carbonate. These dolomitic limestones can often exhibit relicts of an original ooidal or bioclastic texture or may have undergone total recrystallization which has effectively destroyed any trace of the original fabric. The best known dolomitic building stones are probably those of the early Permian succession of north Nottinghamshire and south Yorkshire e.g. Mansfield, Cadeby and Tadcaster stones, but dolomitic limestones can also locally within other intervals of the geological succession.

\section{The stratigraphic distribution of Britain's building limestones (Figure 1)}

The geologically oldest limestones used as building stone in Britain principally include those of the Precambrian of northern western Scotland. These complex, metamorphosed successions include hard, variegated limestones which were worked in the distant past both for local building stone on the Island of lona and, notably in the late $19 \mathrm{C}$ and early 20C, for use as a polished decorative stone (Viner 1992). This striking marble (white, veined with green, serpentinous minerals) can be seen in the cathedrals of Iona, Edinburgh and Westminster, but did for short time see more widespread decorative usage in Edwardian churches across Britain.

In contrast, the limestones of the Lower Palaeozoic have been locally more important as sources of vernacular building rubblestone. They include the grey Cambrian to Ordovician dolomitic limestones of the Durness Group of North West Scotland and the Silurian grey Wenlock limestones of Shropshire and the Welsh Borders. However, none have travelled far from their local outcrops. The Silurian limestones generally comprise fine-grained, hard, fossiliferous lithologies and were used principally for thinly coursed rubblestone walling. The beds are rarely of sufficient thickness to be used for ashlar, but the coarsely fossiliferous varieties were sometimes selectively cut and polished 
as decorative stones e.g. Ledbury Marble. Despite widespread local usage they are not currently actively worked for building stone.

Despite the widespread extent of the Devonian outcrop, limestones are only developed in the marine middle Devonian succession of south west Britain and they are a particularly evident in the buildings of Devon. They generally comprise massively bedded, grey or pink, marine limestones, locally including fossiliferous reef deposits. In the deeper water facies thin, dark coloured, siliceous chert nodules and layers are also commonly present in the limestones. The limestones were extensively worked for large block stone, widely used in bridges, docks, houses and municipal buildings, particularly in larger population centre such as Plymouth, Paignton and Torquay. They have been used for ashlared window and door mouldings, together with other poorer quality local stones or, as coursed ashlar block or rubblestone in many towns and villages along their outcrop. The limestones include both dolomitic and calcareous varieties.

Locally, partial metamorphism of this Devonian limestone succession has produced colourful 'marbles' which in the $19 \mathrm{C}$ were quarried extensively to provide cut and polished stones. These decorative marbles were widely used in houses (fireplaces etc), churches (tombstones and monuments) and to decorate municipal buildings, most notably in Plymouth, Paignton and Torquay. The Devon marbles were for period in the $19 \mathrm{C}$ also exported to London and elsewhere in the UK, providing decorative columns and cladding for numerous Victorian and Edwardian buildings (Elsden and Howe 1923). One particularly notable example of their use is in the elaborately decorated church at Keble College in Oxford, designed and built by William Butterfield in the $19 \mathrm{C}$.

The grey, occasionaly reddish, limestones of the early Carboniferous are generally massively bedded and were once quarried extensively for local building stone along their outcrops in several areas of Britain. The succession includes both shallow marine, coarsely fossiliferous reef and ooidal limestones and deeper-water limestones which are characterised by dark siliceous chert bands. Used mainly as large block or rubblestone, they are probably best seen in buildings in the Pennine counties of Derbyshire, Lancashire, Yorkshire, Northumberland and Durham. However, they were also an important building stone resource in both South and North Wales, in north Devon and in parts of Somerset. They were commonly used as large squared blocks and not generally exported far from their local outcrop areas. They are seen to great effect in both the medieval Caernarvon Castle and the nearby $19 \mathrm{C}$ Menai Bridge in North Wales. Occasionally, however, the limestone was export to other parts of the UK, It can be seen, for example, in Birmingham Town Hall which was constructed of large fossiliferous blocks of grey Penmon Limestone (Marble) from Anglesey.

In northern England a number of very fossiliferous beds from this early Carboniferous succession were locally important as sources of decorative 'marbles'. These include the black Frosterley Marble of Northumberland, with its striking abundant white coral assemblage, and the black limestones of Ashford-in-the Water in Derbyshire. The widespread export and use, in medieval times, of the black sparsely crinoidal, Egglestone Marble for church monuments and grave slabs across Britain, has been well documented (Badham and Blacker 2009). Derbyshire also produced a wide range of variegated and paler grey-brown, fossiliferous limestones including Hopton Wood, Derby Fossil, Rosewood (red), Bird's Eye etc. Derbyshire marbles are commonly seen in buildings in Derbyshire and further afield in London, most notably perhaps in All Saint's Church, Oxford Street. The fossiliferous Penmon 
and Halkyn 'marbles' of North Wales were also locally important as sources of polished, decorative stone.

In contrast to the limestones so far discussed, some of Britain's most significant building limestones were sourced from the dolomitic Permian (Cadeby Formation) limestone successions of eastern England. They comprise fine to coarse grained, pale yellow to white, ooidal, bioclastic and crystalline dolostones and were used extensively for ashlar or carved stonework in some of Britain's most iconic buildings, including the Palace of Westminster (Lott and Richardson 1997), the minsters of York, Beverley and Southwell; Roche and Selby abbeys and Conisborough Castle. They have been actively quarried since medieval times and are ubiquitous in numerous rubblestone cottages, ashlared manor houses and churches along and adjacent to their narrow outcrop, which extends from Nottingham to Sunderland. The concerns raised by decay and subsequent failure of the dolomitic limestone (principally Anston Stone) used in Palace of Westminster fabric in the 1830's became the basis for many subsequent research studies looking into the effects of pollution on stone decay in Britain (Barry et al 1835). Today there remain a small number of active quarries providing Cadeby Formation dolostones for both the on-going conservation and repair of these iconic buildings and new build projects.

The Jurassic marine limestone successions of Britain, provide some of its most recognisable building stones. In the Lower Jurassic these include the thinly bedded, sparsely fossiliferous, blue-grey and pale yellow, micritic limestones of the Lias Group which have most commonly been used as coursed rubble wallstones. The limestones have been quarried and used in vernacular buildings along the length of its outcrop, which extends from Lyme Regis in Dorset to Whitby in Yorkshire. Unusually, in South Wales, the shoreline deposits of this former 'Liassic sea' are also exposed and are characterised by the more massively bedded creamy white, coarse-grained Sutton Stone, a conglomeratic limestone, which was once worked extensively to provide stone dressings for window and door mouldings in medieval buildings across South Wales (e.g. Llandaff Cathedral, Caerphilly Castle).

The overlying thick, limestone-dominated Middle Jurassic succession has provided many of Britain's best known building limestones. The outcrop, which extends from the Dorset coast to Lincolnshire, is pock-marked with hundreds of quarries and stone mines. Some have probably provided building stone for no more than a few local buildings others, however, have always been and remain today major suppliers of building limestone across southern Britain (Ayres 1998; Thomas 2008). The lower part of the succession (Inferior Oolite Group) includes the strongly orange-brown, sandy and coarsely bioclastic Ham Hill Stone, ubiquitous in the window and door mouldings of houses and churches across the Dorset-Somerset area. Further north the distinctive Doulting Stone, a coarsely fossiliferous limestone consisting of spar-cemented crinoidal ossicles, has been supplying building stone since medieval times to many cathedrals and churches in the local area. Other distinctive limestone beds were quarried at Dundry Hill (sandy bioclastic limestone) and Painswick (well sorted ooidal limestone) in the Cotswold Hills, the latter for period exporting stone as far as London. Stone from the Whittington mines near Cheltenham and are ubiquitous in the buildings of the town and in the vernacular architecture of this part of the Cotswolds in general (Price 2007). 
In Gloucestershire and Wiltshire the limestones of upper part of the Middle Jurassic (Great Oolite Group) succession includes the Box, Corsham, Monk's Park and Combe Down stones, collectively known as the Bath stones. These pale-yellow, massive-bedded, coarse grained, ooidal and sparsely bioclastic limestones of the Bath area have been extensively mined for ashlar block for centuries. The City of Bath and its surrounding area is underlain by hundreds of kilometres of abandoned galleries and shafts and is itself a showcase of stone, displaying these local limestones to great effect in its many historic buildings (Price 1984; Hawkins 2012). By the late 19 C Bath Stone was being widely exported to other cities and towns across southern England including London, Bristol and westwards to Cardiff and its suburbs. A small number of mines are still actively supplying Bath Stone for building purposes.

Further north in Gloucestershire the Middle Jurassic succession is still dominated by ooidal limestones and the outcrop is again pockmarked by numerous small stone quarries. In Oxfordshire the Middle Jurassic Taynton Stone was widely used locally, most notably perhaps in the college buildings of Oxford itself (Arkell 1947). Continuing northwards the outcrop extends as far as South Yorkshire and remains dominated by the ooidal and bioclastic limestones that comprise the Lincolnshire Limestone Formation (Inferior Oolite Group). In this area the unit includes the locally named Stamford, Weldon, Barnack, Ketton and Ancaster limestones among others. Although superficially similar in character to the ooidal limestones further south, with experience they can be differentiated petrologically from the Bath and Cotswold varieties. The Lincolnshire limestones have been worked since at least medieval times and are again ubiquitous in the local vernacular buildings, great houses and estates of the area. They are perhaps best displayed in the great cathedral at and castle at Lincoln. The limestones were exported using local river systems in medieval times for the construction of the five medieval Fenland abbeys of Crowland, Thorney, Ramsey, Peterborough and Ely. From the $15 \mathrm{C}$ the Lincolnshire limestones were also used extensively in the construction of several of the colleges at both Cambridge (Purcell 1967) and Oxford (Arkell 1947). The Lincolnshire limestones are also ubiquitous in the churches of Norfolk where the local the building stones were largely unsuitable for ashlar or carved stonework.

Elsewhere along their outcrop, which extends from the Dorset to Lincolnshire a few other limestone beds of the Jurassic were locally worked for more decorative polished limestones. These principally include the coarse bivalve-rich Alwalton limestone. The known occurrences of Alwalton 'Marble' are quite restricted but it was used to great effect for columns and tombs in both Peterborough and Lincoln cathedrals.

In the Upper Jurassic limestones are again prominent in the succession. Among others, they include the grey and brown, bioclastic and ooidal limestones of the Corallian Group and the white ooidal and bioclastic Portland Stone of Dorset. The Corallian limestones were quarried and used widely along their outcrop as sources of vernacular stone in Dorset under a number of local names including the Abbotsbury, Todber Freestone, Osmington Oolite and Marnhull stones (Thomas 2008). In Yorkshire the Corallian Group includes the fine grained, cream-colured Hildenley Limestone which was used in medieval churches and abbeys of the local area. Portland Stone is perhaps England's most recognisable building stone and is quarried (and now mined) on the 'isles' of Portland and Purbeck in Dorset. Since the $17 \mathrm{C}$ the main market for these very durable ooidal and shelly limestones has been London, where many of the principal government buildings have subsequently been constructed 
using this thickly bedded white limestone (Trim 1991; Plate 1). As a building stone it has withstood the polluted city environments of the city better than any other. Buildings of note in London using Portland Stone include St Pauls and Westminster cathedrals, Greenwich Naval College, the Foreign and Commonwealth Office and in the numerous $18 \mathrm{C}$ churches built by Christopher Wren and colleagues. Portland Stone was also widely exported for use in the civic buildings in several provincial cities including Birmingham, Nottingham, Leeds and Cardiff.

The Lower Cretaceous succession is dominated by non-marine clastic successions with only a few limestones present in southern England. These limestone developments occur in the lowest part of the succession close to the Jurassic / Cretaceous boundary. In southern England and includes a repetitive sequence of thin, non-marine limestone beds commonly termed the 'Purbeck Marbles'. Present only in the Isle of Purbeck area these gastropod-rich limestones have provided Britain's most widely used indigenous decorative stones. The limestones have been worked since medieval times using shallow adits and the Isle of Purbeck is pock-marked by scores of old shafts entrances. These hard limestone beds have been individually named by the quarrymen and when polished exhibit a range of textures and colours. They have been used extensively for columns and tombstones in numerous churches and particularly cathedrals across England since at least medieval times e.g. Exeter, Winchester, Salisbury, Westminster, Lincoln and Durham cathedrals (e.g. Leach 1978).

In southern England the overlying clastic Wealden Group includes a further series of thin nonmarine, fossiliferous limestones which were also once locally important sources of decorative stone but also used widely for paving stone. Known of collectively as 'Sussex Marble' they include the locally named Bethersden, Charlesworth and Petworth stones. Occasionally these marbles have been confused with those of the underlying Purbeck succession, but in general the Sussex marbles are dominated by bivalve assemblages and not the typical gastropod faunas of the Purbeck stones.

Limestone developments are comparatively rare in the Lower Cretaceous successions outside southern England. In the shallow marine basin of the north Lincolnshire-East Yorkshire area, however, the Tealby Limestone is well developed and has been worked locally for building stone. This strongly ferruginous, pale yellow-brown limestone was used extensively in the past as a source of large ashlar block principally for use in church architecture in the local area but was not generally exported far beyond its source quarries

In sharp contrast the Upper Cretaceous successions of Britain are dominated by fine-grained, white Chalk limestone lithologies. Locally, in Norfolk and parts of the Lincolnshire a thin basal unit of strongly reddened Chalk is also developed which has been used for building purposes near its principal outcrops, most notably around Hunstanton. In general, however, the principal building stones were sourced from the white limestones of the group. The white chalks were extensively used as a source of both block stone and rubblestone for farm buildings and occasional houses along the whole of their outcrop, which extends from the Dorset coast to Flamborough Head in Yorkshire. In Dorset the best known Chalk building stone is known locally as Beer Stone and is a petrographically distinctive, finely bioclastic facies which only occurs in this area. It has been mined along the coast in this part of Dorset for dimension stone since Roman times and is still widely seen as decorative window and door mouldings in churches and other buildings across the area. The Beer Chalk mines closed only recently leaving a major gap in stone supply to this part of Dorset's World 
Heritage coastline. The remainder of white Chalk Group outcrop has been quarried for local building stone use at several other localities. It has been marketed under a number of local names including the Cambridge Clunch and Totternhoe stones (Dunstable Priory and Woburn Abbey). Further north, in Lincolnshire and East Yorkshire, there are also many churches and vernacular farm buildings in which large parts of their fabric are of Chalk block or rubblestone.

The Chalk Group succession of southern Britain, south of the Wash, is also characterised by the presence of regular bands of hard, siliceous, grey and black nodular flint bands, that have been extensive quarried or gathered for use in walling. In Norfolk, Suffolk and Sussex the local churches are particularly noted for their decorative panels (flushwork), inset with knapped (cleaved) black and grey flints (Hart, 2000). North of the Wash, however, the flints within the Chalk Group are generally unsuitable for knapping and are only occasionally seen as isolated blocks in churches and rural building.

In the Tertiary successions of Britain limestones are a comparative rarity as much of the area was one of marginal-marine and terrestrial deposition. Deposition in the London Basin during the Palaeocene was dominated by marine clay depositionwhich in places include beds containing carbonate cemented concretions. These large concretions $(>30 \mathrm{~cm})$, known as 'Septarian Nodules', were locally of importance as building stone in an area where other suitable indigenous stone lithologies are very limited (Potter 1999).

Further to the south in the Hampshire Basin two limestone units are developed which are of particular note. The Bembridge Limestone Formation includes a coarsely bioclastic limestone interval of restricted occurrence known as Quarr Stone found only in the Isle of Wight. This limestone which is no longer exposed was a significant building stone resource in the past and used particularly in medieval churches and buildings of the island and subsequently exported to the mainland (Winchester Cathedral). The rest of the formation is characterised by a finer grained, more thickly bedded, grey, non-marine limestone known as the Bembridge Limestone Large blocks of this limestone, which was widely quarried, were used extensively in the Isle of Wight area and exported to the mainland (Lott 2011). In Norfolk in the Pliocene, the bioclastic limestone forming the Coralline Crag Formation, provided a limited supply of stone for local building as in Wantisden Church in Suffolk (Dixon 2012).

During the Quaternary porous limestone deposits known as tufa regularly formed around outgassing carbon dioxide-rich spring lines and along streams and river courses associated with older limestone deposits. These tufas, which initially might appear to be an unlikely building material, on subsequent lithification provide a durable, low density stone commonly used in the past in the construction of vaulted ceilings. During the Quaternary there were several areas within Britain where large areas of calcareous tufa were deposited. They were subsequently quarried and occasionally used as building stone in Derbyshire, North Wales, the Isle of Wight, Kent and Gloucestershire. The church at Shelsey Walsh in Worcestershire, for example, is constructed entirely of squared blocks sourced from a nearby tufa deposit.

\section{Britain's building sandstones}


The term framework grain mineralogy describes the mineralogical composition of the detrital grains that form the principal components of sandstones. In most durable British building sandstones the framework grains are dominated by quartz, with subordinate feldspar and lithic (rock) fragments. An over-abundance of the less resistant mineral grains such as feldspar, carbonate (fossils) or glauconite could compromise the sandstone's long-term durability. The common presence of mica grains in some sandstones, often as layers or laminae, can result in a stone which when weathered delaminates. Such laminated micaceous sandstones are generally better suited for producing roofing or paving stones and are unlikely to provide a reliable block stone. Most British building sandstones are cemented by silica, in variable proportions, making them reasonably resistant to weathering and decay. Other intergranular sandstone cements include various carbonate and iron compounds, are comparatively rare in Britain's principal building stones.

In general in the older Precambrian to Carboniferous sandstones are more mineralogically mature, with the grain framework dominated by detrital quartz with subordinate rock (lithic) fragments and low proportions of other mineral grains, including feldspars and micas. In younger Triassic to Cretaceous sandstones quartz grains still dominate but often the feldspar grain proportions increase producing sub-arkosic and arkosic lithologies. The non-marine sandstones which principally characterise the Carboniferous, Jurassic and early Cretaceous successions may also include significant proportions of carbonaceous plant debris and more ferruginous cements which can again compromise the durability of a stone. In contrast, the marine sandstones of the early Cretaceous commonly contain concentrations of the mineral glauconite, a green iron-silicate which can be susceptible to weathering. However, such broad mineralogical changes must be used with caution when provenancing a building sandstone. The relatively young (early Tertiary) Sarsen sandstones, for example, show a mature quartz dominated grain framework, pervasively cemented by silica producing a very durable stone which on mineralogical grounds alone might be considered to have come from a much older more mature geological source.

The natural porosities and permeabilities exhibited by different sandstones can also be key to their durability and therefore longevity when subsequently used in a building. Most current British building sandstones have a porosity of between $15-20 \%$. Originally this pore system provided a pathway for mineral-rich fluids to enter the sand body and precipitate as natural cements between the framework grains. When a stone is set in a building fabric these same pore systems can allow fluids to enter and leave the stone with altogether more damaging results. The past precipitation of industrial pollutants (soot, salts - sulphur, halite etc) carried by the elements onto a building fabric and into the pore systems, has in the past led to serious surface staining and initiated problems of more fundamental decay. The legacy of damage caused by such pollutants is still very much in evidence in many of Britain's sandstone buildings and monuments. Remedial action to deal with the problems arising still remains the focus of much current research into building stone decay and failure (Odgers and Henry 2012).

\section{The stratigraphic distribution of Britain's building sandstones (Figure 2)}

The building sandstones in Britain principally occur within its Cambrian, Devonian, Carboniferous, Permian, Triassic, Jurassic, Cretaceous and Tertiary successions. There are usually sufficient 
petrographic differences between these sandstones to enable the determination of their provenance when identified in a building or stone structure.

Cambrian, Ordovician and Silurian sandstones crop out in Wales and the Welsh borders, the Lake District, the Southern Uplands and Highlands of Scotland. They have been used widely as a local vernacular building material since at least medieval times. In general they range from mineralogically mature quartzose sandstones, with pervasive silica cements (quartzites) but also include less mature sandstones with abundant lithic grains. The Cambrian lithic sandstones of North Wales which were quarried extensively for the construction of Harlech Castle and also used as walling stone for farms and older village buildings in the local area (Lott 2010). In the Cambrian successions of the Wrekin in Shropshire white quartzitic sandstones are also distinctive lithology and commonly appear in local field walls and farm and village buildings e.g. Stiperstone Quartzite in Shropshire. Sandstones are a comparative rarity in the Silurian succession in Britain but when present have occasionally been used locally near their outcrops as vernacular building stone (e.g ??).

By contrast the variegated red, pale brown and green sandstones of the Devonian (Old Red Sandstone) were very important sources of local building stone in Devon, Cornwall, Somerset and Herefordshire. They have been used for ashlar, rubblestone, paving and as a roofing stone. Today they are not widely quarried and only occasionally have they travelled further afield, as for example at No 1 the Poultry, London, where the red Wilderness Stone is used in contrast with yellow Australian sandstone. The Devonian sandstones were also important as a local source of stone roofing slates, particularly in the Herefordshire area where the finer grained, more fissile beds were once worked extensively and can still be found on many local rural buildings. In Scotland Devonian sandstones crop out extensively along the Midland Valley around the Moray Firth, in Caithness and the Orkney and Shetland islands. The fluvial sandstones include variegated varieties some of which have been quarried extensively as block stone as at Kingoodie. However, perhaps the best known of the Scottish Devonian sandstones are those described collectively as the Caithness Flagstones. These very fine, laminated, dark grey-brown sandstones have long formed the basis of a vibrant paving stone industry. They can be raised in very large slabs of consistent thickness and are have been used extensively as paving stones in most of Scotland's towns and cities, and have been regularly exported to other parts of Britain and overseas.

Far and away the most prolific sources of building sandstones, however, lie within the Carboniferous succession, which remains the most important and most extensively quarried building stone resource in Britain today. Sandstone for building has been quarried since Roman times from the Carboniferous of North-West England (Northumberland and Durham), the Pennines (Derbyshire, Yorkshire, Lancashire) and in the coalfield areas of Wales, Somerset, Derbyshire, Yorkshire, Lancashire and in the Southern Uplands and Midland Valley of Scotland (Hyslop et al. 2006). These areas still form the core of Britain's modern building stone industry and, because of their variety and durability are most commonly specified for new build projects. The sandstones, include white, yellow, grey and green varieties and range from fine to coarse grained, some with common pebbly grit beds (Craigleith, Stancliffe, Bramley Fall etc; Figure 2). Mineralogically they can be broadly divided into coarse, quartzose sandstones, with pervasive quartz cements, which primarily characterise sources in the Millstone Grit Group, and the finer grained lithic sandstones sourced from the overlying Coal Measures. Changes in framework grain composition are particularly well 
displayed in the North Somerset and South Wales coalfield areas where the late Carboniferous Pennant sandstones generally show framework mineralogies, which includes high proportions of feldspar and argillaceous rock fragments (PLATE 2).

The succeeding Permo-Triassic successions of the south-west (Devon), the English Midlands (Warwickshire, Worcestershire, Shropshire, Cheshire and Nottinghamshire), the north-west (Cumbria) and in south west Scotland (Dumfrieshire) are generally characterised by a predominant red coloration (Plate 1). In Cumbria the dark red Penrith and paler red St Bees sandstones are still quarried, while in Dumfrieshire quarries at Locharbriggs, Corsehill and Corncockle also supply their red sandstones to current markets. In some areas, however, grey and white sandstone beds are also locally developed in this overwhelmingly red Permo-Triassic succession. In the $19 \mathrm{C}$ they were and were worked extensively for block stone at Storeton, Grinshill, Shawk etc. These 'white' sandstones were often locally preferred for more prestigious buildings and structures (Plates 1 \& 3 ). In Nottinghamshire the red sandstones were locally represented by Red Mansfield Stone (Town Hall at East Retford). This very fine grained, dolomitic sandstone was once much sought after as a decorative stone and used in many $19 \mathrm{C}$ Victorian buildings across southern England, including the highly decorative façade of the Grand Hotel, St Pancras. However, this unique early Permian sandstone development was of limited extent and by the 1920's was completely worked out, leaving something of a problem for modern day conservation projects.

The geological changes that occurred at the end of the Triassic are marked in Britain and elsewhere in Europe by a major switch from non-marine arid depositional environments, with their characteristic red sediments, in the Permian and Triassic, to a long period of marine sedimentation during the Jurassic. In Britain the Jurassic succession is dominated by limestone deposition and sandstone developments are much less significant. Locally, however, the rock succession that marks this transition does include occasional fine-grained quasi-marine sandstone developments. One such sandstone interval, which was particularly significant in its local area as a building stone, is known as the Quarella Stone in South Wales. Outcropping near Bridgend this fine, greyish green sandstone ('Rhaetic sandstone') was extensively quarried and used in many local buildings including the $19 \mathrm{C}$ Margam Castle, some local churches and many terraced houses.

In Britain the Jurassic outcrop extends from the south coast of Dorset to the Yorkshire coast and it is also exposed in isolated outcrops in the islands of north-west Scotland and along the Moray coast. In England the succession is limestone dominated. There has been limited local use, however, of marine sandstone developments from the Lower Jurassic (Bridport Stone) in Dorset and of the ferruginous sandstones cropping out in Northamptonshire (e.g. Helmedon Stone) and both have been used locally as vernacular rubblestone and occasionally as ashlar (Sutherland, 2003; Lott 2011).

Locally, the fissile, calcareous, silty and sandy beds of the Inferior Oolite and Great Oolite groups were once mined extensively for roofing stone at Collyweston (Lincolnshire) and Stonesfield (Oxfordshire). Neither pale-yellow coloured 'slate' is now worked, but they can still be seen in abundance, showing their characteristic diminished courses, on numerous roofs in their local areas (Figure 3). Today, despite a potentially high demand, and considerable efforts to revive the industry there has been no commercial stone roofing slate production from these areas for some considerable time. 
In contrast to southern Britain, the Yorkshire Middle Jurassic (Ravenscar Group) succession is dominated by non-marine sediments which include significant sandstone beds. In the $18 \mathrm{C}$ and $19 \mathrm{C}$, past sandstone quarrying was from the evidence of the numerous Jurassic sandstone buildings still surviving, a major local industry. These pale grey-brown, fine to medium grained sandstones were of sufficient quality to supply good ashlar block for many churches and houses in the area, and some stone (Whitby or Aislaby Stone) was also exported by sea to London. Today these sandstones are still quarried on a small scale from the Saltwick Formation in the Whitby area and remain an important source for both local new build and conservation repair.

Outcrops of Middle Jurassic sandstones are comparatively limited in Scotland. Along the north east coast around Brora the Middle-?Upper Jurassic sandstones were worked for local use at Clynelish. Isolated outcrops in the Isles of Skye and Mull were also worked on a small scale for local vernacular building use (Hyslop et al. 2006).

A marked change in deposition at the end of the Middle Jurassic is evident in the sandstones of Upper Jurassic of the North Yorkshire area which are of marine origin. These fine to medium grained, yellow-buff in colour and often strongly bioturbated and commonly include very large marine fossil assemblages and were formerly worked extensively for building stone. They can be seen in numerous church fabrics in the local area which are constructed of large ashlar sandstone blocks. The characteristic large size of the blocks suggests that from an early stage that the quarrymen recognised that they were comparatively soft and easily weathered. Today some sandstone blocks are showing significant cavitational erosion and decay but unfortunately, no quarries are currently working these sandstones in the North Yorkshire area, a problem replicated across many parts of Britain with regard to obtaining new stone from traditional vernacular stone sources.

Returning south, the marine mudstone-dominated Upper Jurassic successions of the Oxford and Kimmeridge Clay formations also includes the fine grained, grey-green, glauconitic and bioclastic sandstone beds still extensively quarried around Chilmark and Tisbury (Wiltshire) and particularly well displayed in the vernacular rubblestone villages and farms and also as ashlared block in the fabric of Salisbury Cathedral and in the older buildings of the town.

Within the Jurassic of Central England there are several locations where strongly ferruginous and calcareous sandstones are locally developed in both the Jurassic and early Cretaceous successions, most of which have been locally quarried and used as vernacular building stone. These iron-rich beds show a complex interplay of ferruginous lithologies which often defy simple classification as sandstone, limestone or ironstone. They include the ferruginous beds of the Marlstone Rock Formation (Lias Group), Northampton Sand Formation (Inferior Oolite Group), the Corallian Group and Carstone (Lower Cretaceous) respectively. These coarse, occasionally bioclastic 'ironstones' (locally including true ooidal ore-quality developments) have a very distinctive impact on the local vernacular architecture with their wide range of variegated orange-brown, yellow, red and green (when unoxidised) colour variants.

Sandstones are also particularly characteristic of the Lower Cretaceous succession of south east England. They are commonly fine-grained, white or greenish grey in colour and, as building stones, rarely travel far from their source areas. In south east England (Kent, Sussex) these fine grained, nonmarine sandstones, which form part of the Wealden Group (Tunbridge Wells, Cuckfield and Horsham 
stones), were extensively quarried and are still well displayed in the vernacular architecture of the local villages (This volume: Lott and Cameron 2005). Today a small number of quarries are still providing these Wealden sandstones for repair and new build projects. Locally, around Horsham, these fine grained, calcareous, sandstones can be split into thick irregular slabs and are still worked for roofing stone. They are occasionally seen in the local houses showing their typical diminishing courses (Hughes 2003).

Higher in this Lower Cretaceous sequence the sandstones show a marked change in character. Here they are marine sandstones, commonly characterised by siliceous, cherty or calcareous cements. They commonly display a strong green coloration from the presence of the mineral glauconite. These marine 'greensands' from both the Lower Greensand Group and Upper Greensand Formation are comparatively soft but were widely used as rubblestone and large ashlar block in buildings along much of their outcrop across south east England (in Kent, Sussex, Hampshire, the Isle of Wight and Dorset). They have plethora of local names including the Folkestone, Pulborough, Kentish Ragstone (and Hassock), Malmstone, Reigate, Green Ventnor stones. The sandstones of the Upper Greensand succession south of London were in the distant past mined extensively along their outcrop from Brockham in the west eastwards through Reigate to Godstone. The sandstones from this general area are commonly termed Reigate Stone and the mines, which cover a substantial area and still exist but are not worked, supplied large quantities of the grey, glauconitic sandstone to the City of London from Roman to Medieval times. Reigate Stone, among others, can still be seen in the remnants of London's Roman Walls, in parts of Westminster Abbey and in the Tower of London (Burgess 2008). In the Isle of Wight these Upper Greensand glauconitic sandstones were also once widely quarried for building stone and are still well displayed in many buildings on the island, for example at Wroxall, Niton and Ventnor (Lott 2011). Returning north, in Lincolnshire the Lower Cretaceous succession also includes another prominent green, glauconite-rich sandstone bed termed the Spilsby Sandstone Formation. Again despite its comparative softness was widely used as large ashlar and rubblestone blocks in churches and occasionally houses on and adjacent to its rather limited outcrop.

Many of these weakly cemented 'greensands', while providing a strikingly different building stone, have left a legacy of decay which is proving problematic to deal with, as there are currently no quarries actively producing glauconitic sandstones to match all the many historic varieties once quarried.

The Lower Cretaceous successions of Norfolk, and to a lesser extent in the western part of Cambridgeshire, are stratigraphically condensed and lithologically complex. Consequently the vernacular architecture of the area of East Anglia shows a wide variety of quite distinctive rubbly building stones (Allen 2004). Among these are orange brown, ferruginous sandstone known locally as the Carstone (Carrstone). Carstone has been used extensively in churches and cottages across Norfolk and to a lesser extent in Cambridgshire, as both ashlar block but also as large and small rubblestone blocks (Large and Small Carr). These sandy ironstones are particularly evident in villages like Sandringham and Dersingham. Perhaps the most impressive Carstone building in the area is the medieval cathedral at Ely which uses a mix of this local sandy ironstone with contrasting pale yellow Lincolnshire Limestone ashlar dressings. More rarely non-ferruginous, siliceous sandstones or 'Silver' 
Carstone are developed in this Lower Cretaceous Norfolk succession which were also sparsely used in the local vernacular buildings (Allen 2004).

There are no building sandstones present in the Chalk-dominated Upper Cretaceous succession of Britain.

The geologically youngest of Britain's building sandstones occur in the Tertiary succession of south east England. Locally termed 'sarsen sandstones' they are probably best known for their use as large monolithic blocks in Stonehenge. However, they also formed the basis of a much later $19 \mathrm{C}$ quarrying industry and are very much in evidence in the local churches and farm buildings of both Wiltshire and Sussex. The grey sandstones (Greywethers) are generally coarse grained and pervasively silica-cemented and consequently are hard and durable. They are the surviving weathered and eroded remnant blocks from the once much more extensive, sand-dominated Woolwich and Reading Formation succession.

Occasionally, in the Tertiary successions of the London and Hampshire basin areas, very coarse grained, yellow-brown, strongly ferruginous Tertiary sandstones, known locally as 'heathstones' were quarried and used for building. Though rarely found in substantial quantities, in the absence of better quality stones, they were commonly used along with other local stones (like the conglomeratic Hertfordshire Puddingstone), as rubblestone in variable proportions in churches, village walls and only occasionally in houses (Potter 1999; Thomas 2008).

\section{Britain's igneous building stones (Figure 3)}

Igneous intrusions, with few exceptions, are largely restricted to the rugged western and northern areas of Britain. They include a wide range of both 'fine' grained rocks (dykes and sills) and coarse grained granitic varieties. Close to their outcrops vernacular buildings constructed from roughly dressed blocks can quite common. Cornwall and Devon's dominantly grey granites were used extensively in the past in vernacular buildings either as large field gathered 'moorstone' boulder rubblestone or as roughly dressed and coursed stones. By the $19 \mathrm{C}$ the 5 principal granite bosses were the location of many large quarries using modern quarrying and cutting techniques to supply the market across much of southern England. The crystalline fabric of the rocks is quite varied and includes medium to coarse grained texxtures as well as the very distinctive coarsely porphyritic variety known as Luxullianite. The Trowelsworthy granite is a pink coloured granite, a rarity in south west England.

In the $19 \mathrm{C}$ coarse grained 'granitic' rocks were also quarried for local building and monumental stone in the Midlands (e.g. pink Mountsorrel and green Groby granodiorites, Leicestershire), North Wales (grey Trefor), the North West (Cumbria - pink porphyritic Shap) and more extensively in Scotland (Dumfrieshire, Aberdeenshire) (Figure 3). The Scottish granites in general show a wider range of even grained, non-porphyritic textures and a wide specrum of colour variations, colours, from grey (Kemnay, Creetown) to pink (Correnie) and including darker red varieties (Peterhead, Ross of Mull).

While the widespread decorative use of polished granites is clearly evident in the façade's Britain's monuments and town and city buildings, the vast proportion of granite production was supplied as 
roghly dressed blockstone for the construction of major engineering works. Granites were particularly important for the construction of dockyards and lighthouses. In southern Britain the grey Cornish and Devonshire granites are clearly evident in the naval dockyards of Plymouth, Portsmouth, Sheerness (Peterhead) and Southampton, where Rubislaw granite was also used. London's once extensive dockyards contain a wide mix of grey southern granites with much Scottish granite also used. Scottish granites are also commonly seen in many of the older Thames bridges - Tower, Blackfriars, Southwark (with Peterhead), Vauxhall, Kew and Putney all use some Kemnay granite. In the north-west the dockyards at Liverpool and Birkenhead used the red granites from quarries across the Solway at Creetown and Craignair. Along the east coast of England Kemnay granite was used for dock construction at Newcastle and Hull.

Gradual improvements in cutting technologies and transportation meant that by the mid-19 C more than 100 granite quarries were in operation across Britain providing both building and polished decorative stones to supply the Victorian building boom. Production reached a peak in the late $19 \mathrm{C}$ and early $20 \mathrm{C}$ but has since declined dramatically. Today only a small number of British producers remain in Cornwall, Devon, Leicestershire and North Wales. In Cumbria the pink Shap Granite is still quarried, however, in Scotland granite production for building and decorative stone has virtually ceased. Kemnay grey granite was extensively used in Aberdeen, most notably for Marischal College, and the quarries were recently revived to produce the grey granite used in the new Scottish Parliamentary Building in Edinburgh.

In south west England the local term elvan is used to describe the many and varied coarse grained intrusive 'dyke' rocks that are associated with the later phases of granite intrusion in the area. The distinctive colours and coarse textures of these stones can make them readily identified in a building or monument, but in general their use as a building stone was limited in extent as they can sometimes weather poorly. Locally many other fine-grained intrusive rocks were often quarried in the past for building stone. Perhaps one the most evocative use of igneous building stones in Britain is in parts of Hadrian's Wall, historically dividing Scotland from England. Locally quarried dark greyblack dolerite from the Whin Sill was used extensively by the Romans to construct long sections of this defensive wall. Along parts of its route the original Wall still stands and crosses the craggy sill outcrops with vestiges of the original quarries still visible below. In more recent times such hard finegrained igneous lithologies across Britain were more commonly worked to provide stone sets for kerbing, paving and road making.

The production of building or decorative stone from some of Britain's finely grained, extrusive igneous rock outcrops was in the past locally important in a few areas. Around Exeter in Devon a number of scattered outcrops are present and form part of the Exeter Volcanic Group. These reddened and variegated volcanic rocks (known locally as trap) commonly showing vuggy textures and were worked in numerous small quarries at, for example, Pocombe, Posbury and Hardwick. In the absence of a suitable local ashlar, they were commonly used for window and door mouldings. In Northern Ireland the local Tertiary Antrim basalts were occasionally used for wall stone in buildings close to the outcrops. 


\section{Britain's metamorphic building slates (Figure 4)}

This group of building stones is dominated by the metamorphic slate rocks which are restricted in outcrop to the older geological terranes of Devon, Leicestershire, north and west Wales, Cumbria and the north-west and north-east of Scotland. Their relatively restricted outcrops belie their historic value and widespread use, particularly as sources of roofing slates. Though many slates were initially only used locally by the end of the $19 \mathrm{C}$ many were exported and used throughout the country, and in some cases exported overseas to America and Australia.

Slate is a common lithology in the Devonian successions of Devon and Cornwall and, perhaps more than anywhere else in Britain, has been quarried and used extensively for both rubblestone for walling and for roofing slate. The local slates are also widely used in the local slate hanging traditions of the counties, protecting vulnerable wall stones from the elements. There have been many different slate beds quarried and used across the county, but probably the best known are those from the quarries at Delabole-Trevithick, Callywith and around Tavistock (Hart 1991). In general, the green and grey Devon slates are thick and show a 'satin'-like finish to their smooth, undulating cleavage faces. Traditionally they are used in diminishing sizes on the roof.

In Leicestershire the Cambrian succession in Charnwood Forest includes the thick, heavy, greenish grey and purple Swithland Slate. Their use was largely restricted to the local area and did not reach national markets.They were again most commonly used in diminishing sizes on a roof but currently are no longer quarried. The Swithland slates were also quarried for tombstone slabs and many survive showing very intricate lettering and decorative carving on their faces. Locally, large angular blocks of the slate rock, mixed with the local igneous rocks, some of considerable size, are commonly seen as a vernacular rubblestone walling material in the Charnwood Forest area.

The best known of the British slates are probably those of the Lower Palaeozoic successions in North Wales. Production of these blue-grey occasionally green, thin, smooth cleaved slates continues to dominate the British slate market. In North Wales the outcrop remains pock-marked with old quarries and mine workings identified by their ever-present tips of slate waste, although currently recycling of the purple and grey crushed slate waste as a decorative garden feature, is itself a burgeoning local industry. There are few areas of Britain where Welsh slate has not been used for roofing. In early buildings some diminishing slate roof patterns are evident but in general the slates were sawn to provide slates of regular sizes and laid equally coursed from ridge to eaves. The Welsh slate resource is seemingly limitless and the industry, currently booming, continues to supply markets at home and world-wide. Locally, many villages are constructed entirely of slate with much of the wallstone comprising sawn off-cuts from the roofing slate production. The revival of the Welsh slate industry in recent years has been marked by the spectacular use of slate in the façade of the new Welsh Millenium Centre building in Cardiff.

Slates were also widely quarried in the more distant past in Mid and west Wales and are still present on buildings in the area (Roach 2002). The local slates were often not of a very high quality and in Pembrokeshire had to be protected using white 'lime mortar coatings'.

In Cumbria, the 'Lakeland' slate industry is thriving and still producing a range of thick, green and dark blue-grey and occasionally reddened slates, from a number of different quarries in the Lower 
Palaeozoic succession. Across the north of England the diminishing patterns of the much-exported green Cumbrian slate roofs, particularly on more prestigious buildings, contrast with the uniformlysized Welsh slates used in nearby ordinary houses.

In Scotland a once thriving slate industry was supported from several local centres across the country, notably at Ballachulish, Macduff, Aberfoyle and Easdale. The dark heavy slates were used locally, but more commonly supplied the cities of Aberdeen, Edinburgh and Glasgow and other growing population centres in the Midland Valley. There is no evidence of them being exported into England in any quantity. Despite a number of recent attempts to revive and reintroduce some varieties back into the market no quarries are currently producing these Scottish slates.

\section{Conclusions}

Studying and documenting the geological and physical characteristics of natural stones, and developing an understanding of their patterns of use, decay and weathering is of fundamental importance in both preserving our existing stone built heritage and in encouraging the use of new natural stone in new build projects. In today's towns and cities our indigenous stone industry has to compete hard with an increasing range of low cost imported stones many of which, while perfectly acceptable in quality, bear little or no comparison to those traditionally used in the local architecture of an area. This is a problem that can only be solved by encouraging a better understanding of local vernacular stone sources and their usage and by developing a greater flexibility in our planning system that will encourage more small scale, cost effective, local stone production to take place.

Gradually the British building stone industry has become increasingly dominated by a relatively small number of large producers, which while still providing stones of good quality, are marketing a much more limited range of stone varieties. Consequently, we currently have a situation in which locating matching replacement stones for the conservation of the many thousands of vernacular buildings and monuments in Britain now under threat, has become a critical problem that requires immediate attention. In order to address this issue the various organisations concerned with the built heritage of Britain have increasingly funded projects to identify these former local quarry sources and where possible encourage their re-opening to re-introduce a much wider range of vernacular stones back into the market place. One such initiative, led by English Heritage, the English Strategic Stone Study, is aimed both at locating both the defunct former building stone quarries and identifying the numbers of standing buildings remaining in which these stones were used. This dataset will clearly establish where significant local markets still remain for such indigenous stones, not only to supply future conservation repair, but also to encourage their use in sympathetic new build projects. It is hoped that it will also encourage current quarry operators to consider diversifying their stone production to meet this potential demand for new stones.

\section{Acknowledgments}

I would like to acknowledge my considerable debt to the work of many past staff members of the British Geological Survey, dating back to its beginnings in 1835, who have meticulously gathered and maintained the information and sample datasets on which this brief review has been based. I would particularly like to thank Don Cameron, keeper of the current national BRITPITS database, without which my understanding of Britain's building stone resources, such as it is, would be very much the poorer. Published with the permission of the Executive Director of the British Geological Survey. 


\section{References}

Allen, J.R.L. 2004. Carrstone in Norfolk Buildings - distribution, use, associates and influences. British Archaeological Reports (British Series) BAR 371.

Arkell, W.J. 1947. Oxford Stone. Faber \& Faber, London.

Ayers, J. 1998. Building the Georgian City. Yale University Press, New Haven.

Badham, S. \& Blacker, G. 2009. Northern Rock: The use of Egglestone marble for Monuments in Medieval England. British Archaeological Reports. British Series 480.

Barry, C., de la Beche, H.T., Smith, W. \& Smith, C.H. 1839. Report on the Selection of Stone for Building the New Houses of Parliament. In Brown, R. A., Colvin, H.M. and Taylor, A.J. 1963. History of the King's Works. (6 volumes).

Burgess, P. 2008. Surrey's Ancient Stone Mines. Published by Peter Burgess.

Cox, M. H. \& Norman, P. (editors). 1930. Survey of London: Vol. 13. St. Margaret, Westminster, Pt. II: Whitehall I.

Dixon, R. (ed) 2012. A Celebration of Suffolk Geology. Geosuffolk.

Elsden, J.V. and Howe, J.A. 1923. The Stones of London. London Colliery Guardian Ltd.

Hart, D. 1991. The building slates of the British Isles. Building Research Establishment.

Hart, S. 2000. Flint Architecture of East Anglia. Giles de la mare Publishers Ltd, London.

Hawkins, D. 2011. Bath Stone Quarries. Monkton Farleigh: Folly Books.

Howe J.A. 1910. The geology of building stones. E. Arnold.

Hughes, T. 2003. Stone Roofing in England. Pp. 32-127 in Wood, C. (Ed) Stone Roofing. English Heritage Research Transactions, Volume 9. GeoSuffolk.

Hull E. 1872. A treatise on the Building and Ornamental Stones of Great Britain and Foreign Countries :arranged according to their geological distribution and mineral character, with illustrations of their application in ancient and modern structures. McMillan \& Co. National

Hughes, T. 2003. Stone roofing in England. Pp. 32-127, In. Wood, C. Stone Roofing. English Heritage Research Transactions.

Hyslop, E., McMillan, A. \& Maxwell, I. 2006. Stone in Scotland. Unesco Publishing.

Leach, R. 1978. An investigation into the use of Purbeck Marble in medieval England. E. W. Harrison \& Sons Ltd. Hartlepool.

Lott, G.K. \& Richardson, C. 1997. Yorkshire Stone for the Houses of Parliament. (1839-c.1852). Proceedings of the Yorkshire Geological Society, 51, 265-272. 
Lott, G.K. 2001. Building stone resources map of Britain. British Geological Survey.

Lott, G.K. 2005. The development of the Victorian stone industry. In. Doyle, P. (Ed) 2008. England's Heritage in Stone. Proceedings of a Conference at Temple Anderson Hall, York March 2005. English Stone Forum.

Lott, G.K \& Cameron, D.G. 2005. The building stones of south east England; mineralogy and provenance. In. Hughes, J.J, Leslie, A.B. and Walsh, J.A. Proceedings of the 10th Euroseminar on Microscopy Applied to Building Materials.

Lott, G.K. 2010. The Building Stones of the Edwardian Castles. Pp114-120. In Williams, D. M. and Kenyon, J. R. 2010. The impact of Edwardian castles in Wales. Proceedings of a conference held at Bangor University, 7-9 ${ }^{\text {th }}$ September 2007. Gomer Press.

Lott, G.K. 2011. Pp. 128-133, Building Stone. In Woods, M. (Compiler). Geology of south Dorset and south-east and its World Heritage Coast. Special Memoir of the British Geological Survey (England and Wales).

Munby, J. 1989. Westmorland Slate at Buckland (Berkshire) and the Bath, 1754. Transactions of the Cumberland and Westmorland Antiquarian and Archaeological Society . 89, pp. 233-248.

North, F.J. 1946. The slates of Wales. Cardiff, National Museum of Wales.

Odgers, D. \& Henry, A. 2012. Stone: Practical Building Conservation. English Heritage.

Potter J.F. 1999. The geology of London Basin churches: the Palaeogene rocks. Tertiary Research, 19, pp. 117-38. Middlesex .

Price, L. 1984. Bath Freestone Workings. The Resurgance Press.

Price, A.J. 2007. Cheltenham Stone. Cotswold's Naturalists Field Club.

Purcell, D. 1967. Cambridge Stone. Faber and Faber Ltd.

Roach, P. 2002. The White Roofs of the St David's Peninsula. Pp. 61-64. In. Coulson, M. 2005. Stone in Wales. Papers from the Welsh Stone Conference Cardiff 2002. Cadw.

Salzman, L.F. 1967. Building in England down to 1540: A documentary history. Clarendon Press.

Schaffer, R.J. 1955. Stone in Architecture. Pp. 837-867. Journal of the Royal Society of Arts.

Senior, J.R. 1989. The selection of dimension and ornamental stone types used in some northern monasteries - the exploitation and distribution of a natural resource. pp. 223-237. In. Gilchrist, R. and Mytum, H. (eds) Archaeology of Rural Monasteries BAR British Series 203.i Yorkshire .

Smith, B.J. \& Viles, H.A. 2006. Rapid, catastrophic decay of building limestones: Thoughts on causes effects and consequences . Pp. 191-197, In Fort, R. et al. (eds) Heritage, weathering and conservation. Taylor\& Francis/Balkema, London, Rotterdam. 
Stanier, P.H. 1985. The Granite Quarrying Industry in Devon and Cornwall. Part 1 1800-1910, Industrial Archaeology Review 7(2) pp.171-189. Cornwall

Sutherland, D.S. 2003. Northamptonshire Stone . Dovecote Press Ltd.

Tatton-Brown,T. 2001. The Quarrying and Distribution of Reigate Stone in the Middle Ages. Medieval Archaeology, XLV: 189-201.

Thomas, J. 2008. Dorset Stone. Dovecote Press, Dorset.

Thompson, D.B. 2004 The Grinshill Quarries from their heyday in Victorian times until 1923. Clive and Grinshill Conservation Group Occasional Publication No.2. Shropshire.

Trim, P. 1991. The Quarrying of Portland Stone. Isle of Portland Heritage Trust.

Tyson, B. 1984. The Troutbeck Park Slate Quarries, their Management and Markets, 1753-1760. Cumberland and Westmorland Antiquarian and Archaeological Society, 84, 67-190.

Viner, D.J. 1992. The lona marble quarry. New lona Press.

Walsh, J. 2000. Scottish slate quarries. Historic Scotland Technical Conservation Research and Education Division.

Warnes, A. R. 1926. Building Stones: Their properties, Decay and Preservation. Ernest Benn Limited, London, 1926

Worssam B.C. \& Tatton-Brown T. 1993 Kentish Rag and other Kent building stones. Archaeologia Cantiana CXII, pp. 93-125 Kent . 


\section{Figures captions}

Figure 1. The principal building limestones sources of Britain

Figure 2. The principal building sandstones sources of Britain.

Figure 3. The principal roofing slate sources of Britain

Figure 4. The principal 'granite' building sources of Britain

\section{Plates}

\section{Plate 1. Building stone quarries of Britain}

1a. Reigate Mines, Upper Greensand Fm., Selborne Gp., Lower Cretaceous.

1b. Portland Stone Quarry, Portland Stone Fm., Upper Jurassic.

1c. Box Stone Mines (Bath Stone), Great Oolite Gp., Middle Jurassic.

1d. Silver Bed Quarry, Lincolnshire Limestone Fm, Inferior Oolite Gp., Middle Jurassic.

1e. Aislaby Quarry (Aislaby Stone), Saltwick Fm, Ravenscar Gp., Middle Jurassic.

1f. Grinshill Quarry (Grinshill Stone), Sherwood Sandstone Gp., Triassic.

1g Corsehill Quarry, (Coreshill Stone) Sherwood Sandstone Gp., Triassic .

1h. Hillhouse Edge Quarry (Huddersfield White Rock), Millstone Grit Gp., Carboniferous.

\section{Plate 2. Typical building limestones of Britain}

(Thin sections: Field of view left to right $8 \mathrm{~mm}$ : plane polarised light:

blue dye=natural porosity)

Plane polarised; stained for carbonate; Blue-dye impregnation showing porosity

2a. Brighstone, Isle of Wight: Chalk squared block, Upper Cretaceous

2b. Thin section - finely bioclastic Chalk, Upper Cretaceous

2c. Foreign and Commonwealth Office, London: Upper Jurassic Portland Stone.

$2 \mathrm{~d}$. Thin section - medium grained ooidal and bioclastic limestone, Portland Stone (Whitbed)

2e. Box village, Wiltshire: Box Ground Stone (Bath Stone), Middle Jurassic

$2 f$.Thin section -, poorly sorted medium to coarse, bioclastic and ooidal limestone

2g. Roche Abbey: Roche Abbey Stone, Cadeby Formation, Lower Permian

$2 \mathrm{~h}$. Thin section - Roche Abbey Stone, Cadeby Formation.

\section{Plate 3 Typical building sandstones of Britain}

(Thin sections: Field of view left to right $8 \mathrm{~mm}$ : plane polarised light:

blue dye=natural porosity; yellow stain=potassic feldspar)

3a. West Kennett, Wiltshire: large, pale grey Sarsen rubblestone, Woolwich and Reading Fm.

3b. Thin section - coarse grained, silica cemented Sarsen sandstone.

3c. Godshill, Isle of Wight: coursed and galleted, ashlar, Upper Greensand Gp.

$3 \mathrm{~d}$. Thin section - fine grained, glauconitic sandstone

3e. Myddle, Shropshire: coursed red and buff sandstone ashlar, Sherwood Sandstone Gp

3f. Thin section - porous, coarse grained, sandstone 
3g. Pateley Bridge - coursed rubblestone, Millstone Grit Gp.

$3 \mathrm{~h}$. Thin section - porous, very coarse grained, angular quartz, quartzose sandstone 
Figure 1. The principal building limestone sources of Britain (active quarries e.g. Kentish Rag)

\begin{tabular}{|c|c|}
\hline $\begin{array}{l}\text { Limestone } \\
\text { occurrences }\end{array}$ & Principal building and decorative limestones \\
\hline Quaternary & Tufa - Dursley \\
\hline Tertiary & $\begin{array}{l}\text { Bembridge Limestone Formation - Quarr Stone } \\
\text { London Clay Formation - Septarian nodules }\end{array}$ \\
\hline Upper Cretaceous & Chalk - Beer, Clunch, Totternhoe, Lavant; Flint nodules \\
\hline Lower Cretaceous & $\begin{array}{l}\text { Lower Greensand Group - Kentish Rag } \\
\text { Tealby Formation - Tealby Limestone } \\
\text { Wealden Group - Paludina 'marbles' - Bethersden, Charlesworth, Petworth } \\
\text { Sussex; Purbeck 'Marble' }\end{array}$ \\
\hline Upper Jurassic & $\begin{array}{l}\text { Portland Limestone Formation - Portland Stone (Roach, Whitbed, Basebed) } \\
\text { Chilmark, Tisbury; } \\
\text { Corallian Group - Abbotsbury, Headington, Hildenley, Wheatley } \\
\text { Roofing slates - Pusey Flags } \\
\text { 'Marbles' - Melbury }\end{array}$ \\
\hline Middle Jurassic & $\begin{array}{l}\text { Great Oolite Group - Forest Marble, Bladen, Blisworth Limestone; Bath } \\
\text { Stone - Box Ground, Corsham, Combe Down, Monk’s Park, Stoke Ground, } \\
\text { Westwood Ground, Weston Underwood; Oundle, Taynton, Windrush; } \\
\text { Stonesfield and Cotswold slates } \\
\text { 'Marbles' - Alwalton, Bowden, Buckingham, Crackement, Raunds, } \\
\text { Stanwick, Yeovil } \\
\text { Inferior Oolite Group - Cotswold, Farmington, Guiting,Whittington, } \\
\text { Cotswold; Lincolnshire Limestone Formation - Ancaster, Barnack, } \\
\text { Casterton, Cave, Clipsham, Ketton, Silver Bed, Stamford, Weldon; Duston, } \\
\text { Collyweston slates } \\
\text { 'Marbles' - Bradford Abbas, Campden, Stamford, Weldon Rag }\end{array}$ \\
\hline Lower Jurassic & $\begin{array}{l}\text { Lias Group - } \text { Ham Hill Stone; Marlstone; Downside, Sutton, Blue Lias } \\
\text { 'Marbles' - Ammonite, Banbury, Marston }\end{array}$ \\
\hline Triassic & Penarth Group - White Lias \\
\hline Permian & $\begin{array}{l}\text { Cadeby Formation (Lower Magnesian Limestone) - Cadeby, Highmoor, } \\
\text { Tadcaster, Roche, Anston, Steetley, Bolsover Moor, Mansfield, Linby, } \\
\text { Bulwell }\end{array}$ \\
\hline Carboniferous & 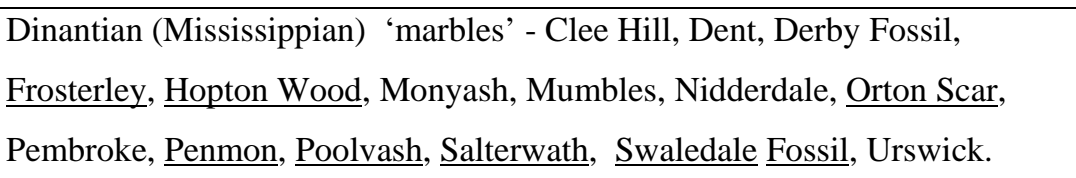 \\
\hline Devonian & $\begin{array}{l}\text { 'Marbles’ - Ashburton, Bradley Wood, Ipplepen, Ogwen, Padstow, Petitor, } \\
\text { Radford }\end{array}$ \\
\hline Silurian & $\begin{array}{l}\text { Aymestry Limestone Formation } \\
\text { Much Wenlock Limestone Formation } \\
\text { Woolhope Limestone Formation }\end{array}$ \\
\hline \multicolumn{2}{|l|}{ Ordovician } \\
\hline Cambrian & Durness Group - Durness Limestone; ‘Marbles’ - Ledmore \\
\hline Precambrian & Marbles - Coll, Iona, Tiree \\
\hline
\end{tabular}


Figure 2. The principal building sandstone sources of Britain (active quarries e.g. Halldale)

\begin{tabular}{|c|c|}
\hline $\begin{array}{l}\text { Sandstone } \\
\text { occurrences }\end{array}$ & Principal building sandstones \\
\hline Quaternary & Heathstones \\
\hline Tertiary & Woolwich and Reading Beds Formation - Hertfordshire Puddingstone, Sarsen \\
\hline Upper Cretaceous & No building sandstones \\
\hline Lower Cretaceous & $\begin{array}{l}\text { Upper Greensand Group- Carstone, Godstone, Gatton, Green Ventnor, Hurdcott, Malmstone, } \\
\text { Merstham, Reigate, Shaftsbury Greenstone } \\
\text { Lower Greensand Group - Bargate, Carstone, Kentish Ragstone, Hassock } \\
\text { Wealden Group - Ashdown, Ardingly, Horsham, Pulborough, Petworth, Sussex Sandstone, } \\
\text { Tilgate, Tunbridge Wells }\end{array}$ \\
\hline Upper Jurassic & $\begin{array}{l}\text { Portland Limestone Formation - Chilmark, Tisbury } \\
\text { Corallian Group - Abbotsbury, Pusey Flags } \\
\text { Garsaig, Clynekirton Sandstone Formation: Clynelish }\end{array}$ \\
\hline Middle Jurassic & 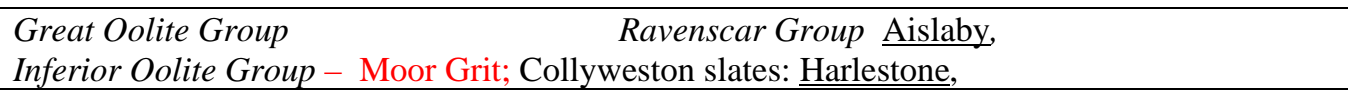 \\
\hline Lower Jurassic & $\begin{array}{l}\text { Lias Group - Bridport Sand Formation, Marlestone Rock Formation; Great Tew } \\
\text { Scalpay Sandstone Formation: Carsaig }\end{array}$ \\
\hline Triassic & 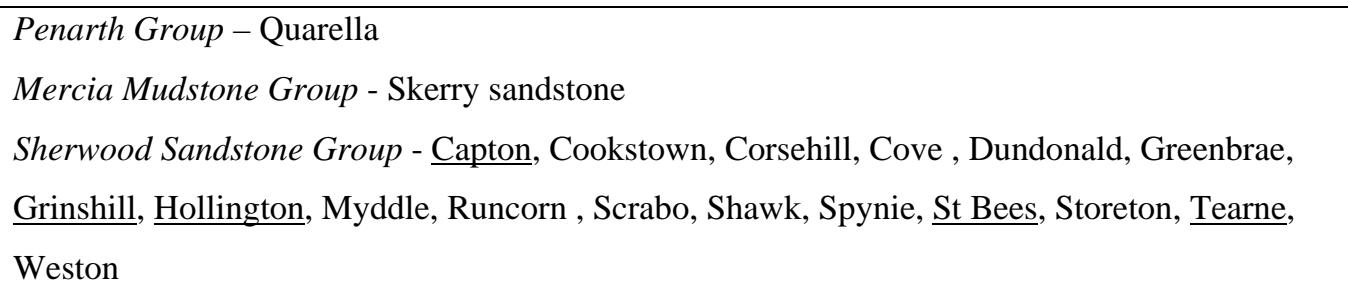 \\
\hline Permian & $\begin{array}{l}\text { Balochmyle, Clashach, Corncockle, Gatelawbridge, Lazonby, Locharbriggs, Plumpton, Shawk, } \\
\underline{\text { Stoneraise, Red Mansfield(d) }}\end{array}$ \\
\hline Carboniferous & 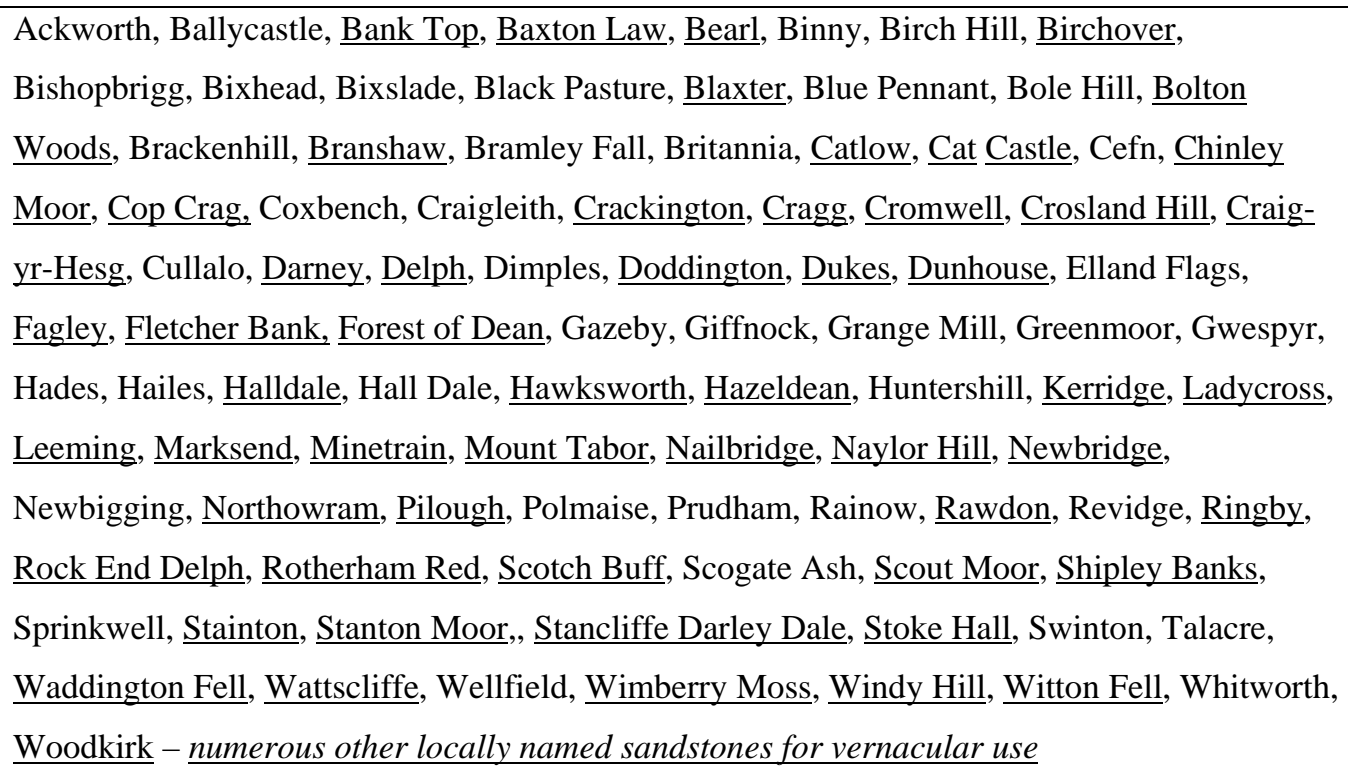 \\
\hline Devonian & 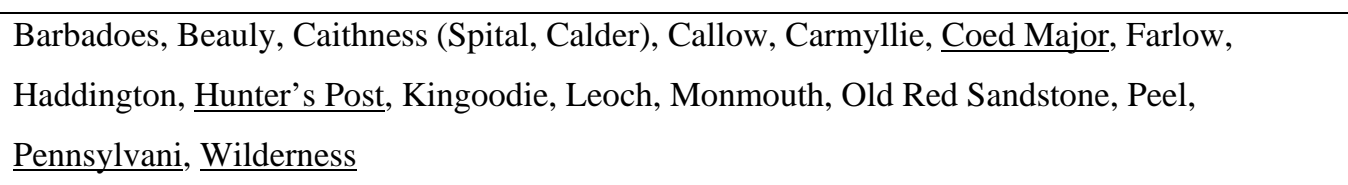 \\
\hline
\end{tabular}


Precambrian, Cambrian, Ordovician, Silurian sandstones - vernacular use only 
Figure 3. The principal 'granite' building stone sources of Britain (active quarries e.g. De Lank)

\begin{tabular}{|c|c|}
\hline England & $\begin{array}{l}\text { Cornwall - Bearah Tor, Boss, Breage, Brownwilly, Burthy, Burtley, } \\
\text { Caradon, Cardynham, Carnebo, Carn Grey, Carnsew, Castle, Castle an } \\
\text { Dinas, Cheeswring, Choon, Colcerrow, Darley Ford, De Lank, Ethorn, } \\
\text { Gredion, Gunnislake, Hensborough, Higher Spargo, Kessle Downs, } \\
\text { Killivean, Kit Hill, Lamorna, Lanivet, Lanlivery, Lower Spargo, } \\
\text { Ludgvan, Luxullion, Mabe, Maen Porth, Mawgen, Mayen, Merrivale, } \\
\text { Paul Hill, Penryn, Pentuan, Penzance, Princetown, Roach Rock, } \\
\text { Rosemorran, Roughtor, Sheffield, St Blazey, St Austell, St Breward, St } \\
\text { Stephen's, Tor, Trannack, Trengrove, Treolvis, Treonweth, Tresare, } \\
\text { Trethwy, Wendron, Zennor. } \\
\text { Devon - Blackenstone, Dewerstone, Haytor, Heale, Heckwood, Lundy, } \\
\text { Pew Tor, Tor, Trowlesworthy, Westcott } \\
\text { Leicestershire - Croft, Groby, Markfield, Mountsorrel, Stoney Stanton. } \\
\text { Cumbria - Eskdale, Threlkeld, Wasdale Head (Shap). } \\
\text { Isle of Man - Micah Mountain } \\
\text { Channel Islands - Les Vardes }\end{array}$ \\
\hline Scotland & $\begin{array}{l}\text { Alvie, Avochie, Barlockart, Benochie, Berneray, Black Hill, Bodham, } \\
\text { Cairngall, Chesthill, Cluny, Corrennie, Corvichen, Cove, Craigdhews, } \\
\text { Craignair, Crathie, Creetown, Cruder, Dalbeattie, Dancing Cairns, } \\
\text { Dereneneach, Dyce, Errol, Globe, Hill ‘o’ Fare, Johnston, Kemnay, } \\
\text { Longhaven, Lumphanum, Mark, Nigg, Park, Persley, Peterhead, Ross of } \\
\text { Mull, Rova, Rubislaw, Sclattie, Seafield, Stirling Hill, Stratherrick, } \\
\text { Tilleyfourie, Tyrrebagge. }\end{array}$ \\
\hline Wales & Gimblet, Graig Lwyd, Trefor \\
\hline Northern Ireland & Mourne \\
\hline
\end{tabular}


Figure 4. The principal roofing stone and slate (italics) sources of Britain (active quarries e.g. Horsham)

\begin{tabular}{|c|c|}
\hline Quaternary & None \\
\hline Tertiary & None \\
\hline Upper Cretaceous & None \\
\hline Lower Cretaceous & $\underline{\text { Horsham }}$ \\
\hline Upper Jurassic & Purbeck, Pusey, Boltby Moor \\
\hline $\begin{array}{l}\text { Middle Jurassic } \\
\text { Great Oolite Group } \\
\text { Inferior Oolite Group }\end{array}$ & $\begin{array}{l}\text { Forest Marble, Bothenhampton } \\
\text { Stonesfield, Kineton,Througham, Collyweston, Duston, Brockhampton }\end{array}$ \\
\hline $\begin{array}{l}\text { Lower Jurassic } \\
\text { Lias Group }\end{array}$ & Ham Hill, Chacombe, Sparkford, Burley Dam \\
\hline $\begin{array}{l}\text { Triassic } \\
\text { Sherwood Sandstone Group }\end{array}$ & Waterstones \\
\hline $\begin{array}{l}\text { Permian } \\
\text { Cadeby Formation }\end{array}$ & Lower Magnesian Limestone \\
\hline $\begin{array}{l}\text { Carboniferous } \\
\text { Westphalian } \\
\text { ( Namurian) } \\
\text { (Dinantian) }\end{array}$ & $\begin{array}{l}\text { Pennant Tilestone, Elland Flags, Wingfield Flags, Dyneley Knoll Flags } \\
\text { Rough Rock Flags,Upper Haslingden Flags } \\
\text { Blacksike Flags }\end{array}$ \\
\hline Devonian & $\begin{array}{l}\text { Caithness Flags, Herefordshire Tilestones } \\
\text { Callywith, Delabole, Lantoom, Tavistock, Tintagel, Trevillet }\end{array}$ \\
\hline Silurian & Brathay Berwyn, Corwen, Horton, Kirby \\
\hline Ordovician & 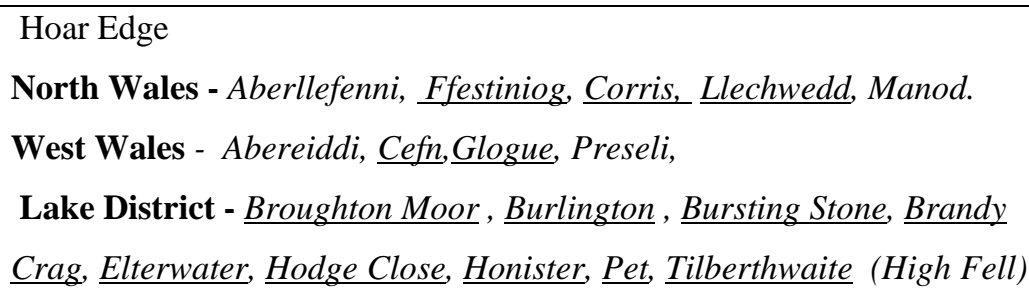 \\
\hline Cambrian & North Wales - Bethesda, Swithland; Nantlle, Penrhyn \\
\hline Precambrian & $\begin{array}{l}\text { Scotland - Easdale, Foudland, Macduff, Dunkeld, Aberfoyle, } \\
\text { Balachullish, Luss }\end{array}$ \\
\hline
\end{tabular}




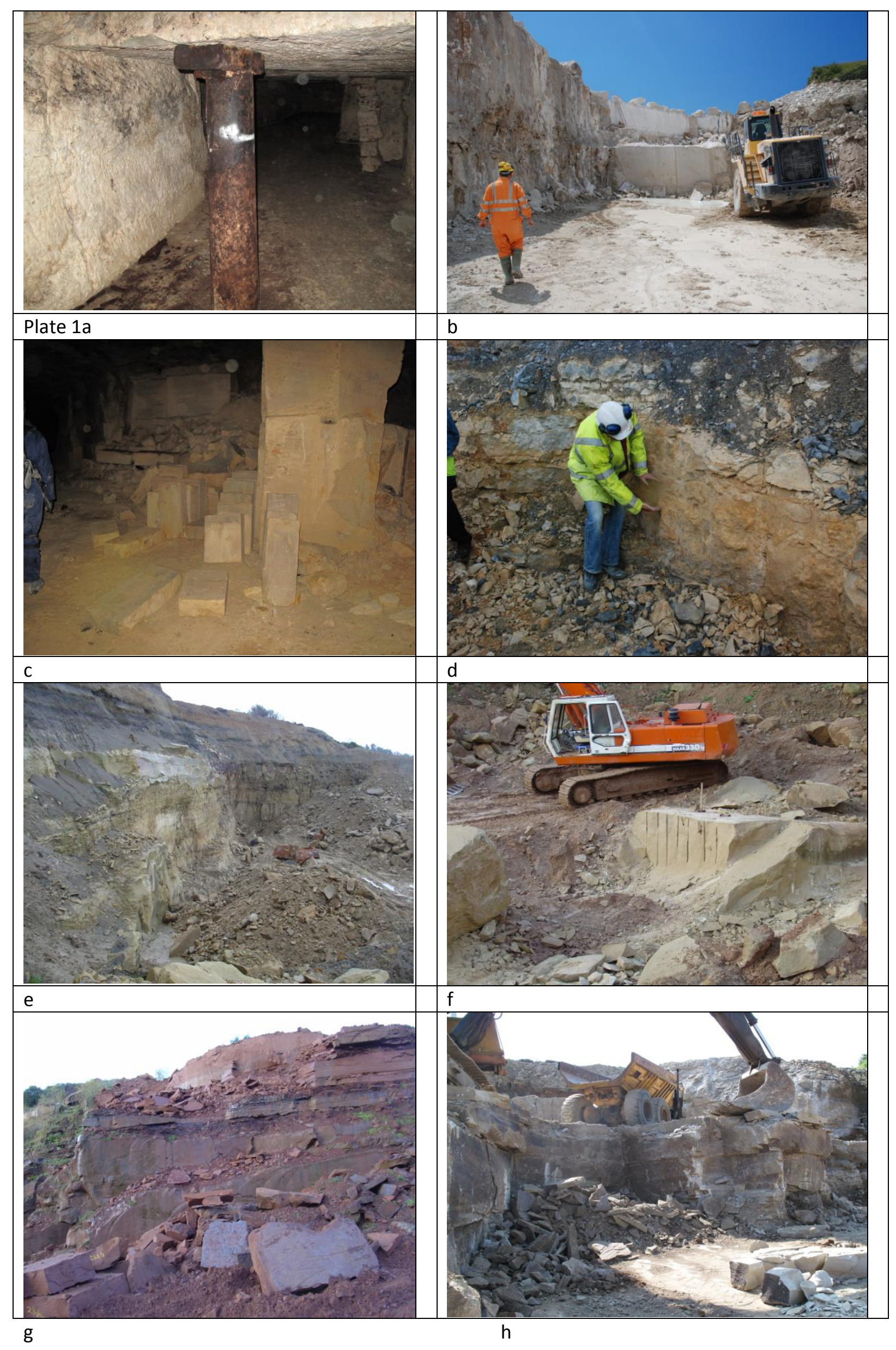









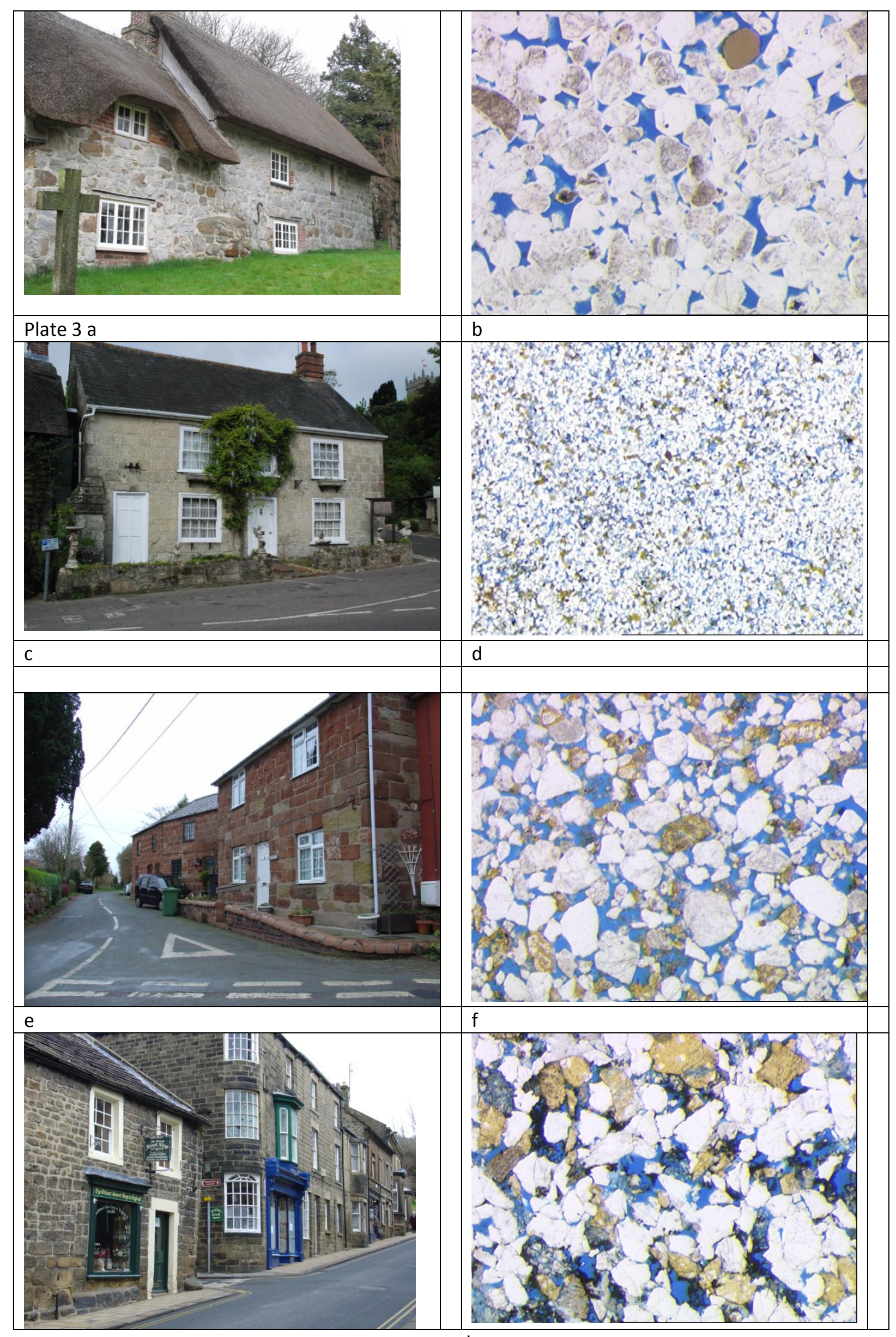

g

h 